\title{
Race, Poverty, and American Tort Awards: Evidence from Three Datasets
}

\author{
Eric Helland* and Alexander Tabarrok
}

\begin{abstract}
We investigate the impact of the race and income of the jury pool on trial awards. We find that the average tort award increases as black and Hispanic county population rates increase and especially as black and Hispanic county poverty rates increase. An increase in the black countypoverty rate of 1 percentage point tends to raise the average personal injury tort award by 3 to 10 percent. An increase in the Hispanic county-poverty rate of 1 percentage point tends to raise awards by as much as 7 percent although this effect is less well estimated. These effects imply that forum shopping for high-poverty minority counties could raise awards by hundreds of thousands of dollars. Average awards fall with increases in white (non-black, non-Hispanic) poverty rates in two of our datasets, thus making these findings even more surprising. Awards increase with black and Hispanic county-poverty rates even after controlling for a wide variety of other potential causes.
\end{abstract}

*Names are in alphabetical order. Alex Tabarrok, Department of Economics, George Mason University, Fairfax, VA, 22030 and Director of Research, The Independent Institute, Email: ATabarrok@ Independent.org. Eric Helland, Dept. of Economics, Claremont-McKenna College, email: Eric Helland@McKenna.edu. The authors wish to thank Michael Krauss and seminar participants at Ball State University, University of Redlands, the Claremont Graduate University and Claremont McKenna College for comments. We are especially grateful to Ted Eisenberg for many helpful comments. 


\section{Introduction}

The effect of juror race and income on the outcome of civil trials has not been well studied. Most of the studies that have been done focus on the disadvantages that poor and minority plaintiffs face before white juries. Implicitly, these studies investigate the interaction between juror and plaintiff race. Yet, it is also possible that majority and minority juries make different decisions independent of plaintiff or defendant race. McClellan (1996, 764), for example, makes the provocative argument that "the only institutions in America where people of color have the power to make immediate wealth redistribution decisions are urban governments and juries." We investigate the wealth redistribution decisions made by people of color on juries. We also examine the effect of juror income on juror decisions.

It is odd that so little attention has been paid to the role of race and poverty in the American tort system because the influence of race on criminal trials has been extensively studied, although the focus there has also been on the interaction between juror and defendant race. In the criminal literature, for example, many studies have found that black defendants are more likely than white defendants to be convicted by white juries, even when, as in mock trials, all else is the same. Studies have also shown that white jurors are more likely than black jurors to convict black defendants. These two findings are often thought to reflect the same underlying cause but this is not necessarily the case. Evidence also exists that white jurors are more likely than black jurors to convict defendants regardless of race - perhaps in part because of greater black juror suspicion of police testimony and conduct. Thus, even if every juror is color-blind it can still be the case that juries of different races reach different decisions in the same cases. ${ }^{1}$

As with the criminal literature, the small literature on juror race and civil cases focuses less on the jury than on the interactions between black plaintiffs and white jurors. The literature finds that minority and low-income plaintiffs are disadvantaged by the civil justice system (McClellan 1996). A RAND study, for example, concluded that black plaintiffs lose cases more often than similarly situated white plaintiffs and receive lower awards (Chin and Peterson 1985). Jury demographics play a role here but only to the

\footnotetext{
${ }^{1}$ On race and criminal trials see, for example, Johnson (1985), King (1993), Bernard (1979), Rosen (1992), Marder (1999).
} 
extent that the typical jury is assumed to be white. Survey and anecdotal evidence also suggests unequal treatment among plaintiffs of different races. ${ }^{2}$

Just as in criminal trials, however, jury demographics may have an impact on civil cases independently of plaintiff or defendant race. Blacks, other minorities, or the poor may perceive the police differently than whites and so decide criminal cases differently than white juries. Similarly, blacks, other minorities, or the poor may perceive corporations and the tort system differently than whites and so decide civil cases differently. $^{3}$

Among the few studies which explicitly examine the impact of jury demographics on civil outcomes are two earlier papers by the authors and an unpublished paper by Eisenberg and Wells (2002) that is complementary to this paper. In two earlier studies we found trial awards increase with county poverty rates, an effect we ascribed to an increase in poverty among jurors drawn from the county jury pool (Tabarrok and Helland 1999, Helland and Tabarrok 2002). The effect of poverty on awards was only incidental to our earlier studies, however, and was not extensively investigated. Eisenberg and Wells find that awards tend to increase in poverty rates but they do not find a racial effect similar to the one that we find. In part, this may be due to a different definition of poverty rates than the one used in this paper - we discuss this difference at greater length below. 4

\section{The Data}

This paper reports results from three datasets. The primary dataset was extracted from Jury Verdict Research's (hereafter JVR) Personal Injury Verdicts and Settlements on CD-ROM. The JVR dataset contains information on 122,444 trials, settlements and arbitrations. The earliest cases were tried in 1988 and the most recent cases date from

\footnotetext{
${ }^{2}$ See McClellan $(1996,774)$ and Patton (1988). The Supreme Court extended its ban on racial peremptory challenges to civil cases in Edmonson v. Leesville Concrete Co., 500 U.S. 614 (1991).

${ }^{3}$ In an experimental study, for example, Kip Viscusi finds that blacks and Hispanics are less able or less willing to follow specific numerical instructions in assessing punitive damages (Viscusi 2001).

${ }^{4}$ Other literature on jury demographics and civil outcomes is anecdotal. Daniels and Martin (1995) refer to

"socioeconomic" factors to explain the variability in awards and win rates that they find across counties but they do not attempt to test this hypothesis or further investigate which socioeconomic factors may or may not be important. A New York Commission also found perceptions "that awards given by juries to minority plaintiffs in civil cases vary in direct relation to the size of the minority population in the county where the litigation is brought, (Report of the New York
} 
1997. All award amounts are corrected for inflation by conversion into 1996 dollars. We are interested in the effect of jury demographics on tort awards so we focus attention on the 42,315 trials, coming from 1803 counties, which resulted in a plaintiff win. ${ }^{5}$ The JVR dataset is useful because of its large size and because it contains information on the case type (product liability, medical malpractice, sexual harassment, premises liability etc.) and on the plaintiff's injuries which lets us control for a wide range of factors other than those of direct interest. The bulk (75\%) of the cases are in auto (51\%), premises liability (14\%) medical malpractice (7\%), or product liability (4\%) cases. We exclude cases in the JVR data that were tried before a judge.

Like other studies, JVR bases most of its results on documents known as court reporters. A potential problem, however, is that JVR also surveys legal newspapers to collect information on cases that it might have missed in its survey of court reporters and this collection strategy may bias attention towards large awards. ${ }^{6}$ Since our focus is the change in tort awards induced by a change in county demographics, oversampling of large awards does not present a problem. Indeed, to the extent that large awards are a subject of particular concern, any oversampling can be beneficial. Without qualification, however, the average awards in this study should not be taken to represent population averages.

To verify results from the JVR dataset we examine two other datasets. The first is from the Civil Justice Survey of State Courts, 1992. The State Court dataset is slightly broader than the JVR dataset as it covers tort, contract and real property cases. All the cases were disposed of between July 1, 1991 and June 30, 1992 in 45 counties chosen to represent the 75 most populous counties in the nation (these counties account for about half of all civil filings.) The dataset is distributed by the Inter-University Consortium for Political and Social Research (ICPSR 6587). The State Court dataset has information on 3199 trials with positive awards. It contains some case type data but does not contain the extensive injury information found in the JVR data. The main defect of the dataset is its

State Judicial Commission on Minorities at 44)." The Commission, however, assumed that the result was due to bias against minority plaintiffs and did not investigate the possibility of a independent role for jury demographics.

${ }^{5}$ Under some conditions, win rates tend towards 50\% regardless of jury characteristics, this makes any relationship between win rates and jury demographics very difficult to identify. See further below and Priest and Klein (1984).

${ }^{6}$ The use of legal newspaper reports is not unusual. Daniels and Martin (1985), Karpoff and Lott (1993, 1999) and Alexander, Arlen, and Cohen (1999) all use data either directly from newspapers or from Lexis/Nexis or court reporters which themselves draw from from legal newspapers. 
relatively small size and the fact that it covers only 45 counties. The advantage of the State Court data is that it is designed to be a random sample of trial awards.

The second supplementary dataset covers Federal court cases. The data are gathered by the Administrative Office of the United States Courts, assembled by the Federal Judicial Center, and disseminated by the Inter-university Consortium for Political and Social Research (ICPSR, 8429). ${ }^{7}$ The dataset is more restrictive than either the JVR or State Court data. First, and most importantly, federal courts draw juries from districts and divisions within districts rather than by county. We call the geographic area from which a federal trial draws a jury a "trial unit." Trial units can range from single counties to subsets of counties to entire states. Trial units, however, never divide a county. Thus, using demographic data on counties, we can aggregate up to create a population weighted demographic dataset on each Federal trial unit. For example, Alabama is divided into the Northern, Middle and Southern District and each of these districts is further divided into divisions each division comprising a number of counties which are listed in the U.S. Code (Title 28). In other cases, however, the U.S. Code does not subdivide districts into divisions but does require that court be held in listed cities. In these states, local court rules rather than the Federal code, determine which counties comprise the trial unit for each of the listed Federal courts. ${ }^{8}$

Since Federal trial units are larger than counties the variation in poverty rates is less than at the county level. Even if demographic effects exist, it will be more difficult to pick these effects up in the Federal data than in the state data. Nevertheless, as our findings are likely to be controversial we wish to examine as many different sources of data as possible.

The Federal dataset has one other limitation, it is top and bottom coded. The top code is at $\$ 9,999,000$ - that is, awards larger than this figure are coded at $\$ 9,999,000$. Awards smaller than $\$ 1000$ are bottom-coded at zero. Bottom coding is likely to be innocuous, however, because the maximum error introduced by bottom-coding is $\$ 999$ while the maximum error induced by top-coding could easily run into the millions of

\footnotetext{
${ }^{7}$ The Federal Court data has been used in a number of papers by Clermont and Eisenberg and is described in greater detail in Clermont and Eisenberg $(1992,1998)$.

${ }^{8}$ An earlier version of this paper aggregated on districts rather than divisions and the even smaller trial units. We are very grateful to Ted Eisenberg for sending us information and data on trial units. A detailed discussion of trial units and how they can be connected to the Federal data can be found in Eisenberg and Wells (2002).
} 
dollars (some $2.5 \%$ of awards in our sample are top-coded.) We will use an interval/censored regression procedure to control for top and bottom coding in the Federal data.

The bulk of Federal court cases concern Federal matters rather than disputes between individuals or individuals and firms. We restrict the Federal dataset to cases broadly similar in type to those in the JVR and State Court datasets, essentially personal injury torts (most of which arise through diversity jurisdiction - suits between persons of different states). As in the JVR data we exclude cases which are tried before a judge. County poverty rates are available only in census years, so we focus on court cases from 1988-1992 thus bracketing by two years on either side the census year 1990. This gives us a dataset of just under five thousand cases. It is worth noting that regardless of our selection, Federal cases are likely to be quite different than state court cases. In addition, as mentioned above, our unit of analysis in the Federal data, the trial unit, is different than the county. Thus, we should not necessarily expect the coefficients to be the same size in all three datasets but we would expect the same signs.

Since the JVR dataset is larger than the State Court or Federal datasets it allows us to break down the data by case type. The JVR data also has more control variables. Thus, we will use the JVR data as our primary dataset and where possible the State Court data and the Federal Court data will be used to check for robustness. As with the JVR data, all award amounts in the State Court and Federal Court data are converted into 1996 dollars.

We supplement the data on trials with data on county demographics drawn from the 1990 census. We hypothesize that the reason awards vary with county demographics is that awards vary with jury composition and jury composition varies with county demographics. The most important limitation of the datasets, however, is that we must infer the average composition of the jury from county demographics. The inference is plausible so long as there is a positive relationship between county and jury demographics - in other words, provided that an increase in the proportion of the county's population that is black (poor, Hispanic etc.) also tends to increase the proportion of jury members who are black (poor, Hispanic etc.) The assumption might have been questionable in the 1960's when jury selection procedures in some parts of the country 
were designed to exclude blacks and other minorities from jury duty but modern selection procedures are designed to ensure that such a positive relationship exists. ${ }^{9,10}$

Although we think it plausible that jury demographics are the causal force behind the correlations we find between average awards by county and county demographics it should be clear that this is a hypothesis. We do not attempt to solve the "ecological inference" problem in this paper. Further research will be necessary to precisely identify the causal forces behind the correlations that we document.

\section{Results}

\section{Exploring the Data: Poverty Rates and Tort Awards}

In Table 1 we split the trials awards into divisions according to the 1990 poverty rate of the county in which the trial occurred. ${ }^{11}$ All trial awards that occurred in a county with a poverty rate of between 0 and $5 \%$ are in division 1 , trial awards that occurred in a county with a poverty rate of between 5 and $10 \%$ are in division 2 and so forth. The data show a marked increase in award by poverty rate. As the average county poverty rate increases from $4.1 \%$ to $21.9 \%$, for example, the average award triples from just over $\$ 400$ thousand to just over $\$ 1.3$ million.

For verification, Tables 2 and 3 report the same experiment using the State and Federal court data respectively. Since the State Court data cover fewer counties the range on poverty is lower as is the poverty range across the Federal trial units. Although the average awards tend to be lower in the State Court data than in the JVR dataset it is clear that the rate of increase with respect to poverty is similar. Awards in Federal Court,

\footnotetext{
${ }^{9}$ The Jury Selection and Service Act of 1968 (JSSA) was passed to ensure that Federal juries be randomly drawn from a "fair cross-section" of the relevant jury pool. Most states have similar laws. The Supreme Court held that race-based peremptory challenges by either the plaintiff or defendant violate the equal protection rights of the challenged jurors

(Edmonson v. Leesville Concrete Co, 111 S. Ct. 2077 (1991)) On peremptory challenges in criminal and civil trials see Raeber (1992).

It is not necessary for our results (nor do we claim) that minority under-representation has been eliminated. On the issue of under-representation see Bueker (1997) and Seltzer, Copacino and Donahoe (1996).

${ }^{10}$ An alternative concern is that economic excuses from jury duty would tend to make minority and low income jurors more common than the county demographic data would suggest. We are less concerned with this than with potential efforts to exclude minorities as this would tend to bias our results toward zero. However, several studies have examined the role of economic excuses and overall the results suggest that excuses do not systematically alter the jury pool (Cecil, Lind and Bermant 1987).

${ }^{11}$ The poverty rate is defined as the number of persons in poverty in the county identified by the 1990 census divided by the county population in 1990 .
} 
however, do not appear to increase strongly with poverty. Figure 1 plots the data from Tables 1,2 and 3.

Regression results, shown in Table 4 strengthen the impression given by Figure 1. The regression estimates are very similar across the JVR and SC datasets; a 1 percentage point increase in poverty rates increases awards by approximately $\$ 35,300$ in the JVR dataset and by $\$ 33,700$ in the State Court dataset. ${ }^{12}$ The regression resuls also suggest a positive, albeit smaller, affect of poverty in the Federal data. A 1 percentage point increase in poverty is estimated to increase awards by $\$ 18,854$ in the Federal dataset. All the results are highly statistically significant (greater than $1 \%$ level). Note that to control for heteroscedasticity we use heteroscedastic-consistent errors throughout our regressions and we control for top and bottom coding using an interval/censored regression procedure in the Federal data. ${ }^{13}$

Examining the JVR data in another way, Figure 2 plots a kernel density estimate of the logged award distribution for low (0-5\%), medium (20-25\%) and high (35\%+) poverty counties. ${ }^{14}$ (The normal distribution fits the logged data quite well, thus suggesting that awards follow a lognormal distribution.) The log mean and variance are higher the higher the county poverty level. Using the kernel densities, we can calculate the probability that an award, in this sample of cases, will be 1 million dollars or larger. The probability is $10 \%, 20 \%$, and $35 \%$ in low, medium, and high poverty counties respectively. (Recall that these awards are conditional upon winning.)

Table 5 breaks the JVR data down into product liability, medical malpractice and auto cases (the other two datasets are too small to examine subsets). Poverty increases awards much more in product liability cases and medical malpractice cases than in auto cases. That is, not only are awards higher in product liability and medical malpractice

\footnotetext{
${ }^{12}$ Following the suggestion of a referee we also restricted the State Court data to make the case types even more similar to those in the JVR dataset - primarly by removing contract, libel and real property cases. The restriction leaves us with 2,272 observations. The results, however, are virtually identical - the coefficient on poverty in the restricted regression is 33, 249.

13 The regressions in Table 4 contains only county level variables (or trial unit level variables in the case of the Federal data); the true number of observations (counties $=1803$ ) is therefore less than the number of award observations $(41,150)$ and the standard errors in Table 3 are inflated. Running the same regression (JVR data) with the average county award as the independent variable, however, leads to very similar results. The reason for presenting the awards regression rather than the county regression is that we shortly introduce case-level variables into the analysis and the presentation facilitates comparisons.

${ }_{14}$ We use a bi-weight kernel with smoothing parameter optimized on the assumption that the underlying data is normally distributed (see Silverman (1986) and Stine (1996) for more information on kernel estimation.) The use of other kernels and/or smoothing parameters does not materially affect the results.
} 
cases, but the rate of increase of awards with respect to county poverty is larger. Figure 3 summarizes in a diagram.

Helland and Tabarrok (1999) show that the average award in product liability and medical malpractice cases is higher than in auto cases even when injuries are held constant. An alternative way of stating the results of Table 4 and Figure 3 is that the markup for product liability and medical malpractice cases is much smaller in low poverty counties than in high poverty counties.

\section{Further Results: Race and Poverty}

The strong and positive relationship between poverty rates and tort awards raises a number of questions. Due to the high rate of poverty among blacks, black population rates and all-population poverty-rates are highly correlated (.53 in the JVR data, .58 in State Court, .46 in the Federal data). To a lesser but still significant extent, Hispanic population rates and all-population poverty rates are also correlated (.33 JVR, .27 State Court, .2 Federal). It's possible, therefore, that poverty is too narrow a variable and is picking up results more properly ascribed to black and/or Hispanic populations of all income levels. Or, it may be that poverty is too broad a variable and that it is picking up results more properly ascribed to low-income black or Hispanic populations.

Regression results in Table 6 attempt to distinguish and evaluate these possibilities. We are interested in the demographics of the jury pool thus we would like to measure, for example, the number of jury-age blacks relative to the total jury-age population. The readily available Census data breaks the age population into divisions such as ages 15-19 and ages 20-24. Using these divisions we created age 20-plus (i.e. age 20 and older) population figures for the black, Hispanic and "white" populations. ${ }^{15}$ Note that we define "white" as non-black, non-Hispanic.

The Census has data on the number of blacks and Hispanics in poverty but does not further subdivide these populations by age. We construct a jury-age black poverty rate by multiplying the total number of blacks in the county below the poverty line by the

\footnotetext{
${ }^{15}$ Age 15-plus and age 20-plus population figures have a correlation of .933 so the age 20-plus population will be an extremely good proxy for the age 18-plus population. To the extent that 18-19 year olds are less likely to serve on juries than those of greater age the age 20-plus figures are superior.
} 
ratio of the 20-plus black population to the total black population and then dividing by the total 20-plus population of the county. We do the same thing for Hispanics.

It is important to recognize that the "black poverty rate" in our regressions is not the percentage of blacks who are in poverty but rather the number of in-poverty blacks as a percentage of the county population (both adjusted by age for jury-eligibility). Given our working hypothesis that jury composition affects awards there is a big difference between a county with a $5 \%$ black population $50 \%$ of whom are below the poverty line (a 50 percent black poverty rate in the usual terminology) and a county where $50 \%$ of the population is black and below the poverty line (a black poverty rate of $50 \%$ according to our usage). ${ }^{16}$

To ease comparison, column one of Table 6 repeats the regression of total awards on poverty. In column two the share of the voting-age black and Hispanic populations are included alongside poverty. All three variables are statistically and economically significant. Note that the size of the coefficient on poverty drops to about a third of that in the poverty alone regressions, suggesting that poverty alone is picking up results more properly ascribed to some combination of poverty, black and Hispanic. According to the regression a 1 percentage point increase in the black population raises awards by 11 thousand dollars while a 1 percentage point increase in the Hispanic population raises awards by nearly 18 thousand dollars.

Column 3 of Table 6 further distinguishes hypotheses by introducing the black poverty rate and the Hispanic poverty rate as variables. With the inclusion of these variables the coefficient on poverty becomes negative and significantly so. The results on the race variables are mixed; the coefficient on black is positive while that on Hispanic is negative but neither is close to statistically significant. The black and Hispanic poverty levels, however, are large, positive, and statistically significant. The suggestion, therefore, is that it is poor black and Hispanic populations that increase awards rather than black and Hispanic populations per se. But these results need to be

\footnotetext{
${ }^{16}$ In their regression, Eisenberg and Wells (2002) use the standard definition of the black and Hispanic poverty rates, rather than our definition that focuses on jury composition. Eisenberg and Wells, therefore, are testing different but complementary hypotheses to the ones that we test. Eisenberg and Wells find that average county awards are not greatly affected by the percentage of blacks or Hispanics in poverty. This result gives credence to our jury composition theory because it tells us that what is driving the result is not a factor associated with high black or Hispanic poverty. Rather, it is the number of blacks and Hispanics in poverty relative to the county population that matters not the number of blacks or Hispanic in poverty relative to the total county population of blacks and Hispanics.
} 
interpreted with caution. As noted above, the poverty rate and the black and Hispanic population rate are highly correlated. The black poverty rate (defined as above) and the black population rate are even more highly correlated (.93). Similarly for the Hispanic poverty rate and the Hispanic population rate (.92).

We perform two robustness tests. In column 4 we remove all counties with black and Hispanic population rates greater than 10\%. The remaining 12,458 observations span counties with poverty levels ranging from $2 \%$ to $62 \%$ so the sample contains significant variation in county poverty rates. Nevertheless, the coefficient on poverty remains negative. Since counties with large black and Hispanic populations have been removed from regression 4 (and are controlled for in regression 3) the negative coefficient on poverty suggests that white poverty (defined as the rate of poverty in the non-black, nonHispanic population) is, if anything, negatively related to tort awards. We follow up on this observation further below.

Distinguishing the influence of black and Hispanic populations from the influence of black and Hispanic populations in poverty is difficult. In order to make this distinction we would need a sample of counties with low poverty rates and large percentages of blacks or Hispanics. Unfortunately, there are almost no such counties in the United States (Prince Georges County in Maryland is the only county in the U.S. with a majority black population and poverty rates below 10\%.) The results in column 3 weakly suggest that black and Hispanic poverty rates are the key variables. In column 5, we present results from a regression of tort awards on black and Hispanic poverty rates excluding the variables for black and Hispanic populations. In addition, following the findings above, we include the white poverty rate. The results indicate that increases in black and Hispanic poverty rates increase awards but increases in white poverty reduce awards. Bearing in mind that further research will be necessary to convincingly separate the influence of poor black and Hispanic populations from black and Hispanic populations in general, we focus in what follows upon this specification. ${ }^{17}$

\footnotetext{
${ }^{17} \mathrm{We}$ have also run this specification using county means. Noting that all variables in the following denote county means and standard errors are in parentheses the regressions results are taward $=202,706(26,552)-4,293 * \mathrm{WPOV}$ $(1,247)+21,373 *$ BPOV $(4609)+66,531 * \operatorname{HPOV}(11,626)$. The regression is weighted to produce robust standard errors. Note that all results are statistically significant at the greater than $1 \%$ level.
} 
A priori, one would expect that awards would fall with an increase in county poverty because wages are lower in counties with high poverty levels and compensatory awards should fall with a fall in wages. We find instead that awards rise strongly with black and Hispanic poverty and fall only with white poverty. The wage-effect should be the same in counties with high proportions of poor whites, blacks or Hispanics. If the coefficient on white poverty is capturing the wage-effect then the increase in awards with black and Hispanic poverty rates is all the more remarkable. In other words, to the extent that white poverty controls for factors, such as the wage effect, which may also be operative in other poor counties, the true coefficients on black and Hispanic poverty are larger by the coefficient on white Poverty. The difference between the coefficient on white poverty and that on black and Hispanic poverty respectively may therefore be considered a difference in difference estimator that controls for any factors correlated with poverty per se.

Columns 6 and 7 of Table 6 present regressions of total awards on white, black and Hispanic poverty in the State Court and Federal Court datasets. Recall that the State Court and Federal dataset are smaller and in the case of the Federal data, more aggregated, than the JVR data. Taking into account the differences among the datasets the results appear quite consistent. Awards in all three datasets increase with black and Hispanic poverty rates although Hispanic is not significant in the Federal data and the sizes of the effects are smaller. The main difference is that in the Federal data awards also increase with white poverty rates.

We turn now to a more detailed analysis that attempts to rule out other possible explanations of these findings through the addition of control variables.

\section{Injuries, Case Types, Cities, and Fixed Effects}

Controlling for other variables will increase our confidence in any discovered relationship between race, poverty and tort awards. We are able to control for injuries, case types, high density counties and state fixed effects. We discuss each of these controls in turn. The JVR dataset has descriptive information on the victim's physical injury such as broken arm, lost leg, cancer, blindness, skin rash etc. We code this information into 3 exclusive and exhaustive dummy variables: Death, Major Injury, and Minor Injury; where Major injuries are defined as those which are permanent (lost leg) 
and minor are temporary (broken leg, skin rash). In addition we also include variables if the plaintiff claims Emotional Distress, Rape, Sexual Assault, Sexual Harassment, or Wrongful Termination.

Case type variables are Premises Liability, Medical Malpractice, Product Liability, Auto, Employment, and Bad Faith Contracting. The vast majority of cases have both an injury and a case type thus the coefficient on Medical Malpractice or Product Liability gives us the increase in awards in these types of cases holding injuries constant. Some Bad Faith cases can involve a plaintiff suing a health insurance company to force the company to pay for a specific treatment, in these cases the injury may be only potential and thus not coded.

For a variety of reasons we might expect awards to be higher in urban counties or counties that include cities. It may be, for example, that high-profile cases with potentially high awards are litigated more often in urban areas than in rural areas. It could also be that the better or more specialized lawyers are located in high density population areas. To control for these effects we include the population density as regressors. Note that the case type variables already go some distance to controlling for larger cases but the population variables will control for any unobserved differences in case types or lawyer quality that are correlated with population density. ${ }^{18}$

State fixed effects are dummy variables specific to each state. To see the importance of including state fixed effects, imagine that there are only two states. The first state has a lot of high poverty counties the second only a few. Assume that the high poverty state has high tort awards but for reasons peculiar to that state and not related to poverty. A regression of awards on poverty will indicate that high poverty rates are associated with high awards. This will occur despite the fact that a high poverty county in the low poverty state will not experience unusually high awards. Including state fixed effects separates state effects from poverty effects, thus forcing the coefficient on poverty to indicate the within-state effect of poverty.

Table 7 contains the coefficients on white, black, and Hispanic poverty once injuries, case types, population density and state fixed effects have been controlled for.

\footnotetext{
${ }^{18}$ We have also experimented with including a dummy variable whenever a county contained an MSA or part of an MSA. An MSA dummy was never statistically significant.
} 
Despite the inclusion of 64 additional variables the results are consistent with those found earlier. (Results on variables other than those of direct interest may be found in Table A1). An increase in white poverty rates continues to decrease awards - a percentage point increase in white poverty rates decreases awards by $\$ 8,600$. Similarly, a percentage point increase in black poverty rates raises tort awards by approximately 20 thousand dollars and a $1 \%$ increase in Hispanic poverty raises average tort awards by 78 thousand dollars. Thus, if white poverty rates control for wage effects the net increase in awards with black and Hispanic poverty may be as high as 28 and 86 thousand dollars respectively.

In Column 2 we show the results from a similar regression using logged awards. Since awards are right-skewed logging them reduces the influence of outliers and also allows for a non-linear relationship between poverty rates and awards. The coefficients on the poverty rates can now be interpreted as the percentage change in awards given a 1 percentage point change in poverty rates. ${ }^{19}$ The coefficient on white poverty rates is negative but small and statistically insignificant. A percentage point increase in the black poverty rate raises awards by 3.2 percent and a similar increase in Hispanic poverty rates raises awards by 7.2 percent. Evaluated at the mean winning award $(\$ 654,627)$ an increase of 3.2 percent is $\$ 20,948$ and 7.2 percent is $\$ 46,478$. Thus the logged and dollar results are almost identical for black poverty rates and similar for Hispanic poverty rates.

Columns 3 and 4 present dollar and logged regressions from the State Court data, this time controlling for injuries (bodily versus property), case types, population density, and state fixed effects. ${ }^{20}$ The coefficient on white poverty is negative but not statistically significant. Black poverty has a positive and statistically significant effect on awards and is larger than in the JVR dataset. The coefficient on Hispanic poverty is anomalous as it switches signs to negative but is statistically insignificant at conventional levels. The Hispanic coefficient is not well-estimated across the datasets - we discuss some possible

\footnotetext{
${ }^{19}$ Note that we do not log the poverty rates - thus we have a semi-log functional form which implies that the beta coefficients can be understood as giving the percentage effect on awards of a unit increase in poverty rates.

${ }^{20}$ In the State Court data a number of states are represented by only one county (these are GA, HI, IN, KY, MN, MO, NY, VA, WA, WI). Since there is no in-state variation in poverty rates in these states, data from these states does not contribute directly to the measurement of the poverty coefficients. The information in these states does, however, help to compute the coefficients on the variables that differ across cases (the injury and case type variables). Better information on the impact of the case variables will improve the estimates of the poverty coefficients thus information from these states contributes indirectly to the measurement of interest. Dropping these states altogether leads to similar coefficients $(-15,000,71,860$, and $-103,600)$ on the coefficients for white, black and Hispanic poverty respectively.
} 
reasons for this further below. The logged awards regression in column 4 has similar results - the coefficient on white poverty is positive but not close to statistically significant (note that in both regressions a 1 standard deviation change will switch the sign), a 1 percentage point increase in the black poverty rate raises awards by $10 \%$ or approximately $\$ 50,000$ evaluated at the winning award mean of $\$ 500,000$ this is smaller than the $\$ 75,000$ estimate from the dollar regression by about 1 standard deviation in dollar awards. The coefficient on Hispanic poverty is smaller ( $\$ 25,000$ at the means) than in the dollar regression but neither estimate is precise.

Column 5 and 6 of Table 7 analyze the Federal Court data both in dollar and logged form. The Federal data does not include injuries or district fixed effects but does include case types, district population density and year dummy variables. ${ }^{21}$ The coefficients on white, black and Hispanic poverty rates are very similar to those found without control variables (all are within one standard deviation). Interestingly, however, the implied effects evaluated at the mean award are all larger when the regression is run in logs. The mean winning award in the Federal data is $\$ 1,169,823$. Thus, evaluated at the mean the coefficients in the logged regression suggest that increases in the white, black and Hispanic poverty rates increase awards by $\$ 48,664, \$ 86,917$, and $\$ 141,080$ respectively.

What can we conclude from these regressions? Several results stand out as robust. Awards increase dramatically in black poverty rates. We estimate that a 1 percentage point increase in black poverty rates increases awards by approximately 3 to 10 percent on average (evaluated using either dollars or logged awards). The feasible range for forum shopping in black poverty rates is at least $10 \%$ which suggests that forum shopping or careful voir dire could raise awards by 30 to 100 percent - hundreds of thousands of dollars. Increases in white poverty rates are uniformly negative in the JVR and State Court Data but positive in the Federal data. The Federal dataset is not large and suffers from difficult problems of aggregation. Thus we would weigh the evidence from the State Court data and especially our primary dataset the JVR data more heavily. Our best judgement, therefore, is that increases in white povety have a small negative effect a 1 percentage point increase in white poverty rates is associated with perhaps a 2 to 3

\footnotetext{
${ }^{21}$ The full regression is reported in Table A3.
} 
percent reduction in awards. It should be born in mind, of course, that jury selection procedures, court rules and judicial oversight could act in ways to make the Federal courts operate differently vis a vis race and poverty than the state courts. Thus our conclusions apply most confidently to the state courts.

There is some evidence that awards increase in Hispanic poverty rates even faster than in black poverty rates, perhaps by 7 percent or more, but the coefficient on Hispanic poverty rates is more variable than on black or white poverty rates and is sometimes negative, depending on the dataset and functional form. In part the problem may be due to imprecision in the term Hispanic. "Hispanic" became a distinct statistical category only in the 1980 census and it was treated as a "race" beginning only in the 2000 enumeration. Until recently, Latin American immigrants were categorized as racially white and multi-ethnic. A majority of Hispanics, understood as those from LatinAmerica, continue to choose white as their race (Etzioni 2002). In addition, usage varies across the country, in California the term Hispanic is widely rejected in favor of Latino while it is more common in Texas and Florida (the term Latino appears for the first time in the 2000 census). Thus, the Census figures need to be adopted with caution.

Even if people of Latin American origin uniformly labeled themselves Hispanic there is still a great deal of variation between, for example, Cuban-Americans in Miami and Mexican-Americans in Los Angeles. Our datasets cover different counties and regions and thus may be picking up differences in the "types" of Hispanics. ${ }^{22}$ If this hypothesis is correct, then if we restrict the JVR data to the year and counties covered by the state court data ${ }^{23}$ and we run the same regression as in Table 7 we should expect to see a negative sign on Hispanic - this is indeed the case. On the restricted JVR dataset the coefficient on Hispanic is $-11,487$. Although considerably smaller than in the SC data and not statistically significant (there are only 1605 observations in the restricted dataset) this result is suggestive that the differences between the state court and JVR data are due to differences in the counties covered in combination with the small size of the state court data. ${ }^{24}$ In future work we hope to break Hispanic and other populations into

\footnotetext{
${ }^{22}$ In addition, in the state court dataset in particular the variation in the Hispanic poverty rate is quite low (the maximum range is $0-8 \%$ in the state court data, compared to $0-30 \%$ in the JVR data and $0-37 \%$ in the Federal data).

${ }^{23}$ Note that the state court data is a random sample from only month. The actual overlap of cases between the restricted JVR and state court dataset, therefore, is likely to be zero or negligible.

${ }^{24}$ Full results are available upon request.
} 
finer, more homogeneous categories that could be used to even more precisely distinguish the effect of demographics on tort awards.

In Table 8 we focus on our largest dataset and further test our earlier finding that the markup in product liability and medical malpractice cases is much higher in high poverty counties than in low poverty counties. To test for this effect we interact the product liability and medical malpractice variables with the black and Hispanic poverty variables. We find clear evidence that awards increase with county poverty much faster in product liability and medical malpractice cases than in other types of cases. A $1 \%$ increase in black or Hispanic poverty increases awards in general by about 11 and 51 thousand dollars respectively. In product liability cases, however, increases in black or Hispanic poverty raise awards by an additional $\$ 124$ thousand and $\$ 213$ thousand respectively. In medical malpractice cases the additional markup is $\$ 36$ thousand and $\$ 162$ thousand dollars respectively. ${ }^{25,26}$

Figures 1 and 3 hint that the relationship between trial awards and poverty rates may be non-linear with the effect of poverty on awards increasing at higher rates of poverty. To test for this we square the black and Hispanic poverty rates and add these to the regression thus allowing the relationship between black and Hispanic poverty and trial awards to follow a quadratic. ${ }^{27}$ The results, presented in column 2 , indicate that awards increase at an increasing rate in black poverty rates but at a lesser rate in Hispanic poverty rates. There is some suggestion that awards may even decrease with black poverty at low poverty rates but the effect is very small. Figure 4 illustrates.

\section{Race, Poverty and Settlement Amounts}

The results indicate that trial awards increase with black and Hispanic county poverty rates and decrease with white poverty rates. Trials are the most visible and

\footnotetext{
${ }^{25}$ Ideally we would like to perform a similar estimate for the State Court and Federal data sets. However in both of these cases the cell sizes are too small for medical malpractice or product liability cases to permit meaningful analysis. ${ }^{26}$ At the suggestion of a referee we also ran separate regressions just on product liability and medical malpractice cases respectively. In both cases, the results were similar (although somewhat larger) than the effects we report. Results are available upon request.

${ }^{27}$ In regressions not reported we found no evidence for a non-linear effect in white poverty rates.
} 
important output of the civil justice system. ${ }^{28}$ Nevertheless, most disputes are settled not tried. It's worthwhile, therefore, to examine settlement data for a poverty effect.

We have data on 26,038 settlement awards from the JVR dataset (neither the State Court nor Federal dataset include data on settlement amounts). Table 9 contains results of a regression of settlement amounts on white, black and Hispanic poverty rates extracted from a regression that includes all of the cont rol variables described above, i.e. state fixed effects, injuries, population density, and case types. A $1 \%$ increase in black poverty rates increases settlement awards by nearly 24 thousand dollars while the same increase in Hispanic poverty rates increases settlement amounts by approximately 18 thousand dollars. When awards are logged we estimate that a 1 percentage point increase in black poverty raises average settlement amounts by $1.6 \%$ and the same increase in Hispanic poverty raises awards by $2.1 \%$ (evaluated at the mean settlement award of $\$ 278,000$ these are $\$ 4,450$ and $\$ 5846$ - somewhat smaller than the estimates from the dollar awards). The coefficient on white poverty rates is positive but small and not statistically significant.

We do not attempt to analyze how win rates, risk aversion, expected award size, the decision standard and other variables affect the relationship between settlement amounts and trial awards (see Priest and Klein 1984, Waldfogel 1995). For a back of the envelope calculation, however, assume that the settlement award is based on the expected trial award. Using an average win rate of $1 / 2$, the above increase in settlement amount with black and Hispanic poverty rates translates into increases in awards conditional on wining of 44 and 36 thousand dollars respectively or (using the log estimates) 3.2 and 4.1 percent respectively. These effects are consistent with those found in the trial award equations.

We have also examined win rates and settlement rates using Probit regressions but in all cases the effect of the various poverty rates was negligible. For example, we found a 10 percent increase in black poverty was responsible for a 0.0408 percent point increase in the probability of winning a case (i.e. plus 0.0408 units in the prob. of winning). Other

\footnotetext{
${ }^{28}$ Trials are the most important output of the civil justice system in the sense that trials are the final output without which no other output is possible.
} 
results were on the same order (results are available upon request). Thus we find that the main effects of poverty rates occurs on awards.

The lack of an effect on win rates is not surprising because the cases that go to trial tend to be coin-toss cases, i.e. cases with a lot of uncertainty in win rates (Priest and Klein 1984). If the plaintiff and defendant can easily predict the outcome of the case, the case will settle because of the potential savings in trial costs. An exogenous change might increase win rates temporarily but as expectations adjust more cases will be settled leaving, once again, the most uncertain cases to go to trial. Under some conditions, trial win rates will always approach 50 percent. Although case selection makes the interpretation of win rates quite difficult this is less true of awards. In the standard PriestKlein model, for example, the distribution of awards is not at all affected by case selection. ${ }^{29}$ A proper test of the effect of poverty on win rates requires information on the trial rate. It is possible to create a trial rate from the Federal data thus a potential test is available following the methods in Waldfogel (1995). We leave such a test to future research.

\section{Conclusions}

The results indicate that awards fall (or increase only moderately in the Federal data) with white poverty levels but increase dramatically with black poverty rates. Awards also appear to increase with Hispanic poverty rates although the results are more variable. An increase in the black poverty rate of 1 percentage point tends to raise the average personal injury tort award by 3 to 10 percent (20 to 60 thousand dollars) and our best estimate is that an increase in the Hispanic poverty rate of 1 percentage point tends to raise awards by 7 percent. Yet awards tend to fall by 2 to 3 percent for every 1 percentage point increase in white poverty rates. A fall in awards is to be expected if compensatory awards fall with a fall in wages, thus the increase in awards with black and Hispanic poverty is especially surprising. Since the variation in county poverty rates is large, moving a trial from a low poverty to a high poverty county can substantially increase the average award.

\footnotetext{
${ }^{29}$ In the standard model the savings from settling rather than trying a case are assumed to be a constant fraction of the potential judgment (e.g. see Priest and Klein (1984) and Waldfogel (1995), setting (C-S)/J=c.) With this assumption there is no selection on awards. Selection on awards can never be strong because if high award cases rarely go to trial their outcome becomes more uncertain which increases the number of these cases that will fail to settle.
} 
Awards increase with black and Hispanic county poverty rates even after controlling for a wide variety of other potential causes including injuries, population densities, case types, any factors, such as legal differences, associated with states and any factor correlated with white poverty rates. Settlement amounts also increase with increases in black and Hispanic county poverty rates. It is unlikely that the difference in awards can be explained by any factors specific to the case or to differences in law. It appears that socio-economic factors can exert large effects on awards thus calling into question a typical assumption of "law and economics" type reasoning.

One hypothesis that could explain our results is that poor black and Hispanic jurors decide cases differently than white jurors of all poverty levels. Given the different life-experiences of poor black and Hispanic jury members, relative to whites of all poverty levels, it appears plausible that the decisions of such jurors about justice and due compensation could differ significantly from those of other jurors. Such a finding is also consistent with the literature on race differences in decision making concerning criminal trials.

We conclude, however, with two cautions. First, we do not have data on the composition of the jury and we must therefore infer jury characteristics from county characteristics. Second, although some evidence suggests that it is poor black and Hispanic populations that are driving the increase in awards rather than black and Hispanic populations per se, the high correlation between these variables makes a definitive statement unwise. Solving these twin problems will require jury level data either from real court cases or from mock trials (much as has been done in the criminal literature). Jury level data could test the inferences about juries that we have drawn from county demographics and, at the jury level, it would not be hard to test whether it is minorities, poor minorities or both factors that are driving the association between blacks and Hispanics and higher awards. In short, we have demonstrated that some robust correlations exist between county demographics and tort awards. We hope that further research will investigate our hypothesis that jury composition is the causal explanation for these correlations. 


\section{References}

Alexander, C. R., J. Arlen, and M. A. Cohen. 1999. Regulating Corporate Criminal Sanctions: Federal Guidelines and the Sentencing of Pulbic Firms. Journal of Law and Economics 42 (1):393-422.

Bernard, J. L. 1979. Between the Race of the Defendant and That of Jurors in Determining Verdicts. Law \& Psychology Review 5:103-.

Bueker, J. P. 1997. Jury Source Lists: Does Supplementation Really Work? Cornell Law Review 82:390-431.

Cecil, J. S., A. E. Lind, and G. Bermant. 1987. Jury Service in Lengthy Civil Trials. The Federal Judicial Center.

Chin, A., and M. A. Peterson. 1985. Deep Pockets, Empty Pockets: Who Wins in Cook County Jury Trials. Santa Monica, Ca.: Rand Corp.

Clermont, K. M., and T. Eisenberg. 1992. Trial By Jury or Judge: Transcending Empiricism. Cornell Law Review 77:1124-77.

---. 1998. Do Case Outcomes Really Reveal Anything About the Legal System? Win Rates and Removal Jurisdiction. Cornell Law Review 83:581-607.

Daniels, S., and J. Martin. 1995. Civil Juries and the Politics of Reform. Evanston, IL.: Northwestern University Press.

Eisenberg, T., and M. T. Wells. 2002. Trial Outcomes and Demographics: Is There a Bronx Effect? Working Paper: Cornell University.

Etzioni, A. 2002. Inventing Hispanics: A Diverse Minority Resists Being Labeled. Brookings Review 20 (1):10-13.

Helland, E., and A. Tabarrok. 1999. The Effect of Electoral Institutions On Tort Awards. American Law and Economics Review 4 (2):341-70.

Johnson, S. L. 1985. Black Innocence and the White Jury. Michigan Law Review 83:16111708.

Karpoff, J. M., and J. R. J. Lott. 1993. The Reputational Penalty Firms Bear from Committing Criminal Fraud. Journal of Law and Economics 36 (2):757-802.

---. 1999. On the Determinants and Importance of Punitive Awards. Journal of Law and Economics 42 (1):527-73.

King, N., J. 1993. Postconviction Review of Jury Discrimination: Measuring the Effect of Juror Race On Jury Decisions. Michigan Law Review 92:63-130. 
Marder, N. 1999. The Interplay of Race and False Claims of Jury Nullification. University of Michigan Journal of Legal Reform 32:285-321.

McClellan, F. M. 1996. The Dark Side of Tort Reform: Searching for Racial Justice. Rutgers Law Review 48:761-798.

Priest, G., and B. Klein. 1984. The Selection of Disputes for Litigation. Journal of Legal Studies 13 (1):1-55.

Raeber, M. M. 1992. Towards an Integrated Rule Prohibiting All Race-Based Peremptory Challenges. Georgia Law Review 25:503-537.

Rosen, J. 1992. Jurymandering. The New Republic 1992 (30 November):15.

Seltzer, R., J. M. Copacino, and D. R. Donahoe. 1996. Fair Cross Section Challenges in Maryland: An Analysis and Proposal. University of Baltimore Law Review 35:127-167.

Silverman, B. W. 1986. Density Estimation for Statistics and Data Analysis. London: Chapman and Hall.

Stine, R. A. 1996. Data analysis using Mathematica. In Computational Economics and Finance, ed. H. R. Varian, 330-61. New York: Telos.

Tabarrok, A., and E. Helland. 1999. Court Politics: The Political Economy of Tort Awards. Journal of Law and Economics XLII (pt.1):157-88.

Viscusi, K. 2001. The Challenge of Punitive Damages Mathematics. Journal of Legal Studies 30 (2(1)):313-50.

Waldfogel, J. 1995. The Selection Hypothesis and the Relationship Between Trial and Plaintiff Victory. Journal of Political Economy 103 (2):229-60. 
Table 1: Mean Tort Awards by Poverty Rate, JVR Data

\begin{tabular}{llll}
\hline \hline Poverty Range & Mean Poverty Rate in Range & Mean Award & $\begin{array}{l}\text { No. } \\
\text { Observations }\end{array}$ \\
\hline $0-5 \%$ & $4.1 \%$ & $\$ 398,874$ & 2714 \\
$5-10 \%$ & $7.5 \%$ & $\$ 470,875$ & 10,373 \\
$10-15 \%$ & $12.5 \%$ & $\$ 647,882$ & 16,018 \\
$15-20 \%$ & $17.4 \%$ & $\$ 670,597$ & 8915 \\
$20-25 \%$ & $21.9 \%$ & $\$ 1,185,010$ & 3150 \\
$25-35 \%$ & $27.8 \%$ & $\$ 1,185,630$ & 1031 \\
$35 \%+$ & $40 \%$ & $\$ 2,661,910$ & 114 \\
\hline $0-100 \%$ & $12.8 \%$ & $\$ 651,241$ & $42,315^{1}$ \\
\hline 1) Slight differences in the number of observations between the sample statistics and \\
regressions are due to missing observations on independent variables. \\
\hline
\end{tabular}


Table 2: Mean Tort Awards by Poverty Rate, State Court Data, 1996 Dollars

\begin{tabular}{llll}
\hline \hline Poverty Range & $\begin{array}{l}\text { Mean Poverty Rate } \\
\text { in Range }\end{array}$ & Mean Award & No. Observations \\
\hline $0-5 \%$ & $3.6 \%$ & $\$ 126,987$ & 199 \\
$5-10 \%$ & $7.6 \%$ & $\$ 260,529$ & 858 \\
$10-15 \%$ & $13.1 \%$ & $\$ 547,978$ & 934 \\
$15-20 \%$ & $17 \%$ & $\$ 664,435$ & 628 \\
$20-25 \%$ & $20.4 \%$ & $\$ 758,347$ & 487 \\
\hline $0-100 \%$ & $12.9 \%$ & $\$ 498,131$ & 3106 \\
\hline
\end{tabular}


Table 3: Mean Tort Awards by Poverty Rate, Federal Court Data, 1996 Dollars

\begin{tabular}{llll}
\hline \hline Poverty Range & $\begin{array}{l}\text { Mean Poverty Rate } \\
\text { in Range }\end{array}$ & Mean Award & No. Observations \\
\hline $0-10 \%$ & $7.9 \%$ & $\$ 1,024,247$ & 891 \\
$10-15 \%$ & $11.6 \%$ & $\$ 1,081,002$ & 2112 \\
$15-20 \%$ & $17.1 \%$ & $\$ 1,586,245$ & 965 \\
$20-25 \%$ & $22 \%$ & $\$ 1,003,034$ & 659 \\
$25-100 \%$ & $29 \%$ & $\$ 1,331,389$ & 157 \\
\hline $0-100 \%$ & $14 \%$ & $\$ 1,169,823$ & 4784 \\
\hline \hline
\end{tabular}




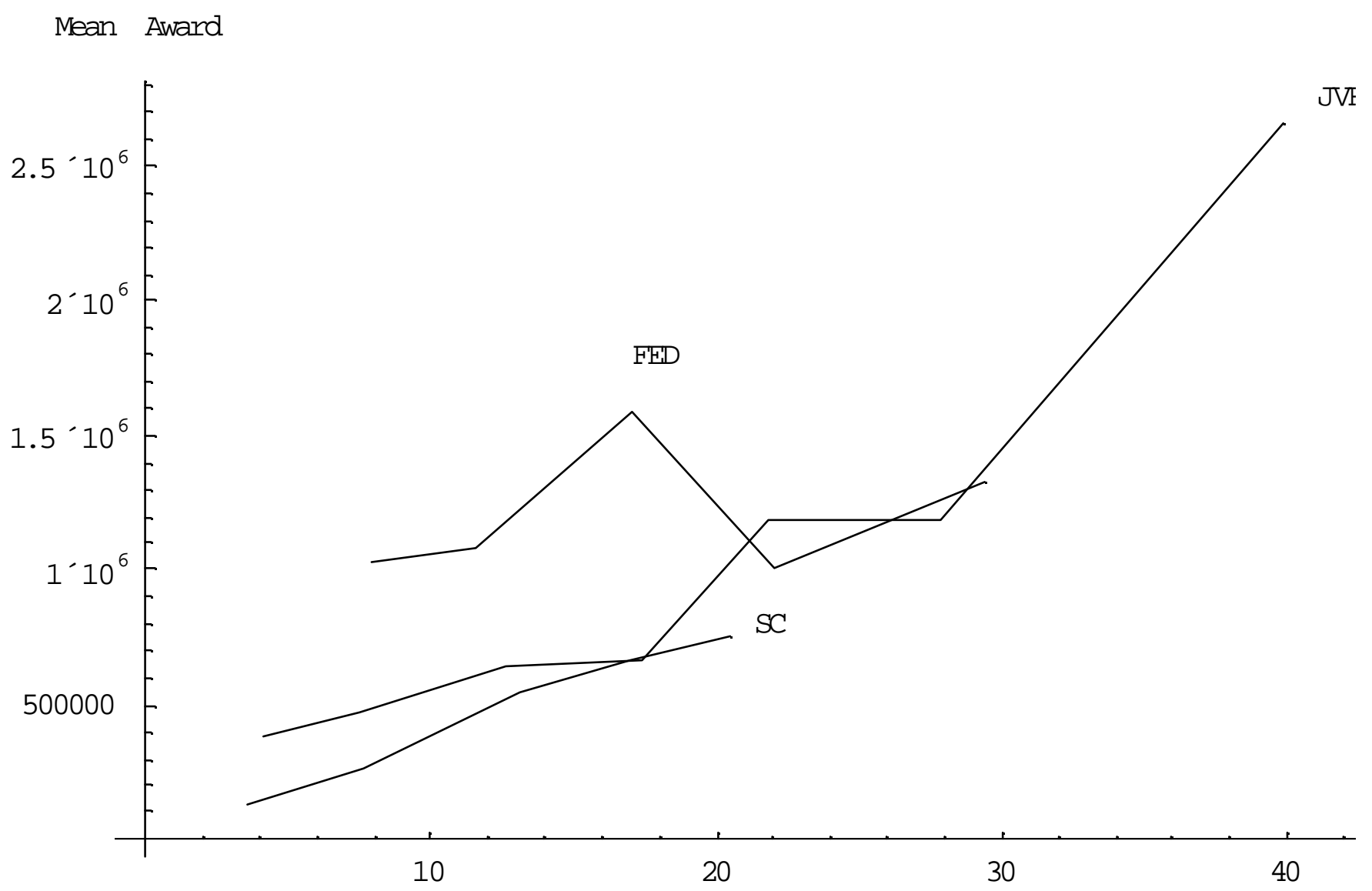

Figure 1: The Increase in Average Tort Award by County Poverty Rate is Similar in the JVR and SC Data but not apparent in the Federal data. 
Table 4: Regression Results, Total Awards on Poverty, JVR and State Court Data

\begin{tabular}{llll}
\hline \hline & JVR Data & State Court Data & Federal Court Data \\
\hline Constant & $187,066^{*}$ & 65,177 & $920,838^{*}$ \\
& $(38,967)$ & $(100,292)$ & $(108,956)$ \\
Poverty Rate & $36,864^{*}$ & $33,476^{*}$ & $18,854^{*}$ \\
& $(3,340)$ & $(10,018)$ & $(7,115)$ \\
Observations & 41,150 & 3,106 & 4,784 \\
\hline
\end{tabular}

* Significant at greater than $1 \%$ level

** Significant at greater than 5\% level.

Standard errors are robust (heterosecadastic-consistent). Federal regression using interval/censored procedure to handle bottom and top-coding. 


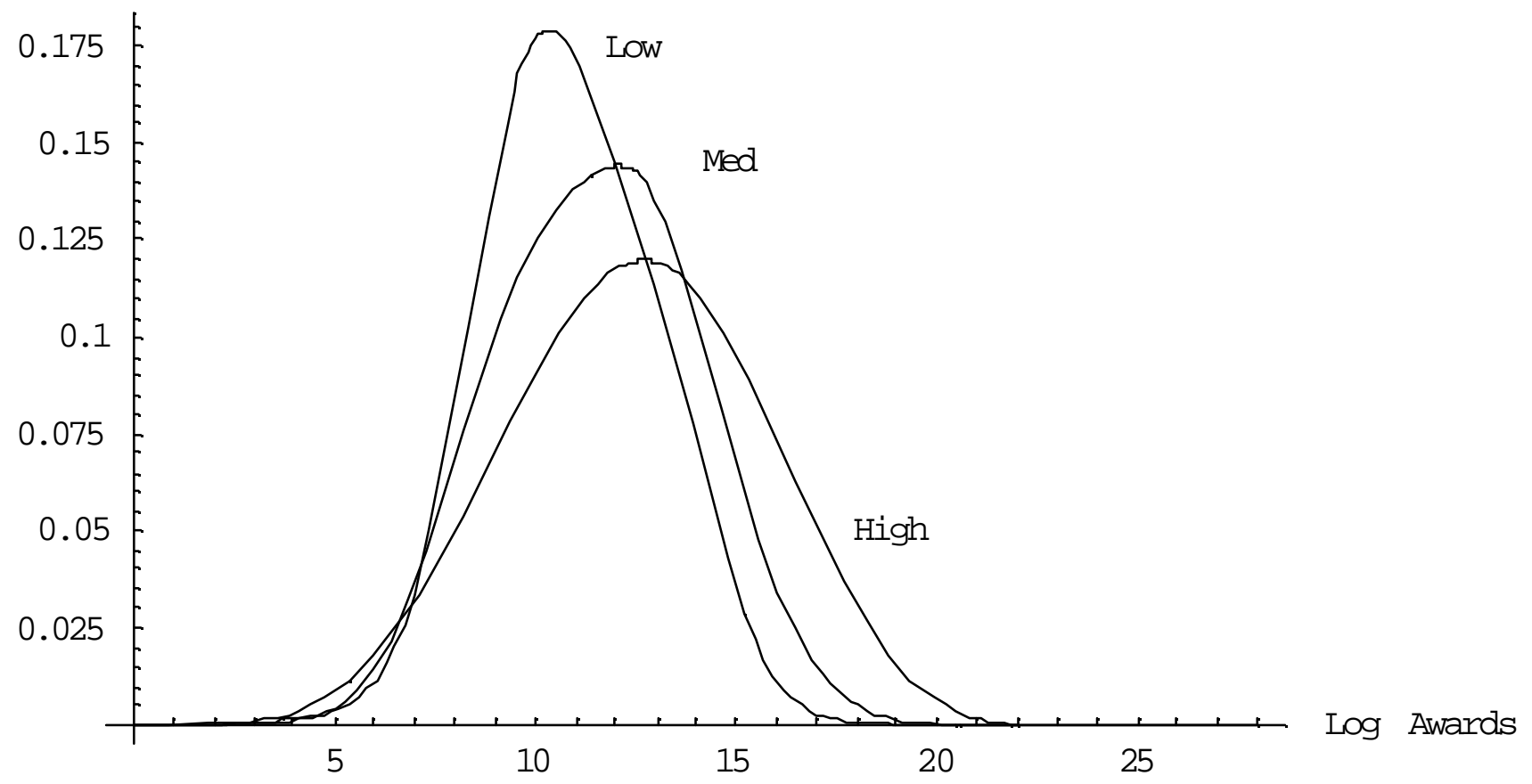

Figure 2: Density Functions for Low, Medium and High Poverty Counties Show that the Mean and Variance of Log Awards Increases with County Poverty Rates 
Table 5: Mean Awards by County Poverty Rate in Product Liability, Medical Malpractice and Auto Cases, JVR Data

\begin{tabular}{lllllll}
\hline \multirow{2}{*}{ Poverty Range } & \multicolumn{2}{l}{ Product Liability } & \multicolumn{2}{l}{ Med. Malpractice } & \multicolumn{2}{l}{ Auto Cases } \\
& Mean & Obs & Mean & Obs & Mean & Obs \\
\hline $0-5 \%$ & $\$ 1,183,410$ & 57 & $\$ 1,077,330$ & 262 & $\$ 243,670$ & 1590 \\
$5-10 \%$ & $\$ 2,279,620$ & 313 & $\$ 1,480,071$ & 601 & $\$ 228,613$ & 5797 \\
$10-15 \%$ & $\$ 1,929,380$ & 675 & $\$ 1,806,510$ & 1083 & $\$ 280,056$ & 8124 \\
$15-20 \%$ & $\$ 2,485,990$ & 512 & $\$ 1,811,420$ & 559 & $\$ 240,540$ & 4103 \\
$20-25 \%$ & $\$ 4,279,320$ & 138 & $\$ 3,105,800$ & 272 & $\$ 544,865$ & 1414 \\
$25 \%+$ & $\$ 6,743,680$ & 45 & $\$ 4,001,020$ & 72 & $\$ 759,719$ & 525 \\
\hline $0-100 \%$ & $\$ 2,441,440$ & 1769 & $\$ 1,851,190$ & 2849 & $\$ 285,069$ & 21,553 \\
\hline
\end{tabular}




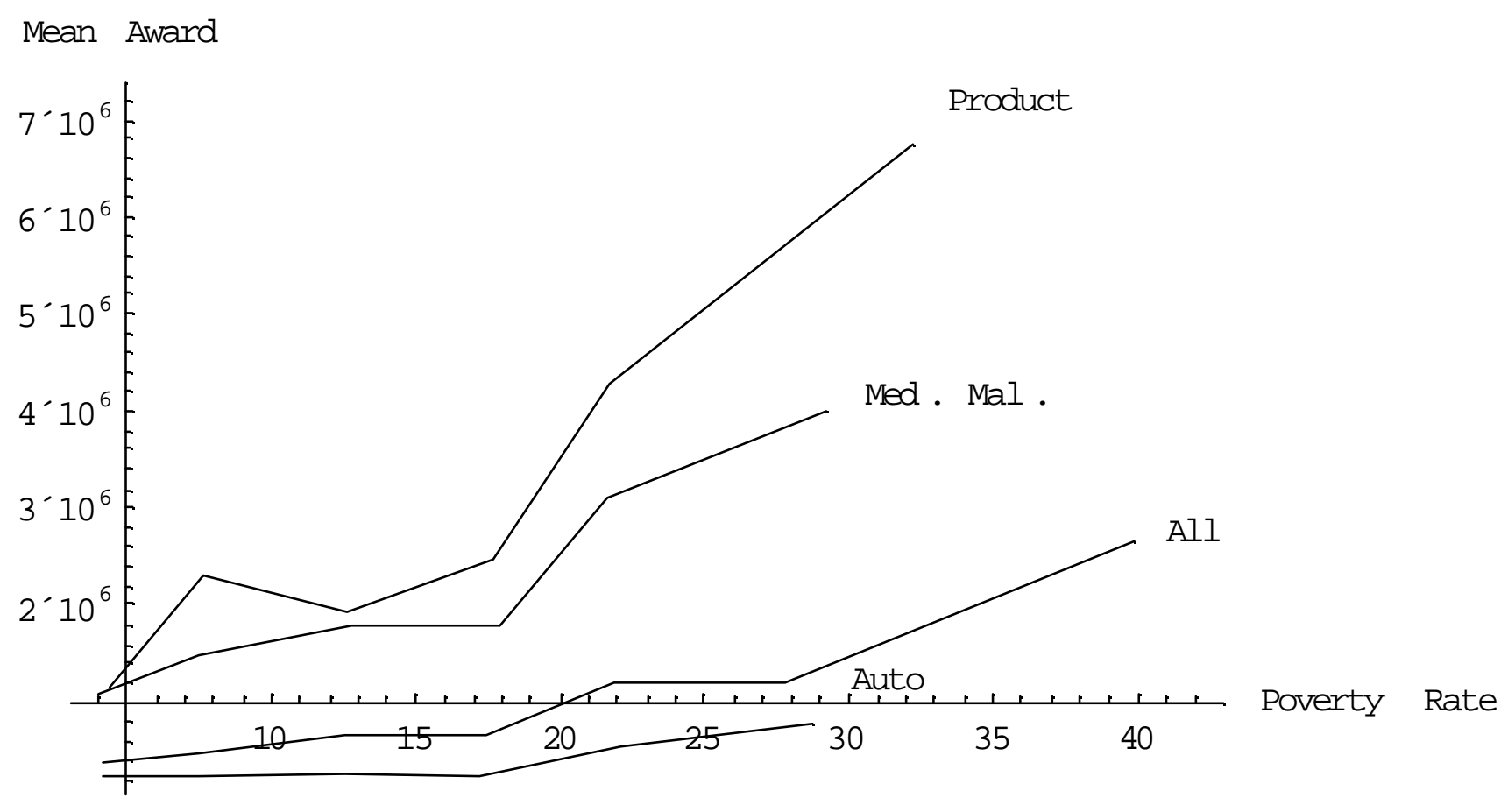

Figure 3: Mean Awards by County Poverty Rate in Product Liability, Medical Malpractice and Auto Cases 
Table 6: Regression of Awards on Race and Poverty Variables

\begin{tabular}{|c|c|c|c|c|c|c|c|}
\hline & (1) & (2) & (3) & $\begin{array}{l}\text { (4) Non- } \\
\text { Minority } \\
\text { Counties } \\
\text { Only }\end{array}$ & $\overline{~(5)}$ & $\begin{array}{l}\text { (6) State } \\
\text { Court } \\
\text { Data }\end{array}$ & $\begin{array}{l}\text { (7) Federal } \\
\text { Court Data }\end{array}$ \\
\hline Constant & $\begin{array}{l}184,967 * \\
(39,055)\end{array}$ & $\begin{array}{l}109,368 \\
(40,236)\end{array}$ & $\begin{array}{l}362,752 * \\
(42,718)\end{array}$ & $\begin{array}{l}449,232 * \\
(35,018)\end{array}$ & $\begin{array}{l}330,279 \\
(34,751)\end{array}$ & $\begin{array}{l}353,102 * \\
(124,356)\end{array}$ & $\begin{array}{l}941,532^{*} \\
(111,541)\end{array}$ \\
\hline Poverty & $\begin{array}{l}36,864 * \\
(3,353)\end{array}$ & $\begin{array}{l}12,257 * \\
(3,014)\end{array}$ & $\begin{array}{l}-8,805 * \\
(3245)\end{array}$ & $\begin{array}{l}-4,768 * * * \\
(2,583)\end{array}$ & & & \\
\hline Black & & $\begin{array}{l}11,090 * \\
(1,541)\end{array}$ & $\begin{array}{l}4,150 \\
(4,925)\end{array}$ & & & & \\
\hline Hispanic & & $\begin{array}{l}17,901 * \\
(1,337)\end{array}$ & $\begin{array}{l}-3,541 \\
(4,046)\end{array}$ & & & & \\
\hline $\begin{array}{l}\text { White } \\
\text { Poverty } \\
\text { Rate }\end{array}$ & & & & & $\begin{array}{l}-4328 * * \\
(1836)\end{array}$ & $\begin{array}{l}-36,198 * * \\
(15,497)\end{array}$ & $\begin{array}{l}14,199 * * \\
(7,108)\end{array}$ \\
\hline $\begin{array}{l}\text { Black } \\
\text { Poverty } \\
\text { Rate }\end{array}$ & & & $\begin{array}{l}30,666^{*} \\
(17,848)\end{array}$ & & $\begin{array}{l}34,251 * \\
(5,370)\end{array}$ & $\begin{array}{l}32,856^{*} \\
(9,319)\end{array}$ & $\begin{array}{l}23,033^{* *} \\
(9,970)\end{array}$ \\
\hline $\begin{array}{l}\text { Hispanic. } \\
\text { Poverty } \\
\text { Rate } \\
\end{array}$ & & & $\begin{array}{l}172,712 * \\
(31,460)\end{array}$ & & $\begin{array}{l}137,725^{*} \\
(11,441)\end{array}$ & $\begin{array}{l}71,390 * * \\
(29,235)\end{array}$ & $\begin{array}{l}18,311 \\
(26,595)\end{array}$ \\
\hline Obs. & 41,150 & 41,150 & 41,150 & 12,593 & 41,150 & 3,106 & 4,784 \\
\hline \multicolumn{8}{|c|}{$\begin{array}{l}\text { * Significant at greater than } 1 \% \text { level. } \\
* * \text { Significant at greater than } 5 \% \text { level. } \\
* * * \text { Significant at greater than } 10 \% \text { level. } \\
\text { Standard errors are robust (heterosecadastic-consistent). } \\
\text { All awards in real } 1996 \text { dollars }\end{array}$} \\
\hline
\end{tabular}


Table 7: Regression of Total Award on State Fixed Effects, Injury Variables, Case Types, Population Density, and White, Black and Hispanic Poverty

\begin{tabular}{|c|c|c|c|c|c|}
\hline \multirow{3}{*}{$\begin{array}{l}\text { 1) JVR } \\
\text { Data }^{1}\end{array}$} & 2) JVR - & 3) State & 4) State & 5) Federal & 6) Federal \\
\hline & Logged & Court & Court - & Court & Logged \\
\hline & Awards & Data $^{2}$ & $\begin{array}{c}\text { Logged } \\
\text { Awards }\end{array}$ & Data $^{3}$ & Awards \\
\hline
\end{tabular}

\begin{tabular}{|l|l|l|l|l|l|l|}
\hline White & $-8,644^{*}$ & -.0038 & $-18,199$ & .03854 & $19,665^{* *}$ & $.0416^{*}$ \\
Poverty Rate & $(2,876)$ & $(.00288)$ & $(30,634)$ & $(.03966)$ & $(8.209)$ & $(.0156)$ \\
\hline Black & $19,838^{*}$ & $.0317^{*}$ & $74,991^{*}$ & $.1001^{*}$ & $18,875^{*}$ & $.0743^{*}$ \\
Poverty Rate & $(6,762)$ & $(.0033)$ & $(21,447)$ & $(.02169)$ & $(10,152)$ & $(.01767)$ \\
\hline Hispanic. & $78,588^{*}$ & $.0717^{*}$ & $-106,159$ & $-.0536^{* * *}$ & 12,344 & $.1206^{*}$ \\
Poverty Rate & $(15,708)$ & $(.00599)$ & $(68,608)$ & .03197 & $(27,405)$ & $(.0491)$ \\
\hline
\end{tabular}

\begin{tabular}{lllllll} 
Obs. & 41,150 & 41,150 & 3,106 & 3,106 & 4,784 & 4,784 \\
\hline
\end{tabular}

* Significant at greater than $1 \%$ level.

** Significant at greater than $5 \%$ level.

$* * *$ Significant at greater than $10 \%$ level.

1. Full Results for this model may be found in Table A1, results on other models are similar.

2. Includes a less extensive set of injury variables than the JVR data also includes case types, density, and state fixed effects. Full Results for this model may be found in Appendix A2.

3. Does not include injury variables but does include case types, district densities and year dummy variables.

Standard errors are robust (heterosecadastic-consistent).

All awards in real 1996 dollars 
Table 8: Regression of Total Award on State Fixed Effects, Injury Variables, Case Types, Population Density, White, Black and Hispanic Poverty - Further Results JVR Data

\begin{tabular}{|l|l|l|}
\hline \hline White Poverty Rate & & \\
& $\begin{array}{l}-9,541^{*} \\
(2,843)\end{array}$ & $\begin{array}{l}-10,775^{*} \\
(2915)\end{array}$ \\
\hline Black Poverty Rate & $\begin{array}{l}11,525^{* *} \\
(5,859)\end{array}$ & $\begin{array}{l}-36,002 \\
(25,550)\end{array}$ \\
\hline Hispanic Poverty Rate & $\begin{array}{l}51,479^{*} \\
(13,588)\end{array}$ & $\begin{array}{l}74,350^{*} \\
(25,504)\end{array}$ \\
\hline $\begin{array}{l}\text { Product Liability*Black } \\
\text { Poverty }\end{array}$ & $\begin{array}{l}124,093^{* *} \\
(55,395)\end{array}$ & \\
\hline $\begin{array}{l}\text { Product Liability*Hispanic } \\
\text { Poverty }\end{array}$ & $\begin{array}{l}213,466^{*} \\
(72,823)\end{array}$ & \\
\hline $\begin{array}{l}\text { Medical Malpractice*Black } \\
\text { Poverty }\end{array}$ & $\begin{array}{l}36,329 * * * \\
(19,977)\end{array}$ & \\
\hline $\begin{array}{l}\text { Medical } \\
\text { Malpractice*Hispanic } \\
\text { Poverty }\end{array}$ & $162,429^{* *}$ & \\
\hline (Black Poverty) $^{2}$ & $(64,046)$ & \\
\hline (Hispanic Poverty) & & $3,724 * *$ \\
\hline Obs & & 289 \\
\hline$*$ Significant at greater & & 41,150 \\
\hline
\end{tabular}

* Significant at greater than $1 \%$ level.

**Significant at greater than 5\% level.

***Significant at greater than $10 \%$ level.

Standard errors are robust (heterosecadastic-consistent). 


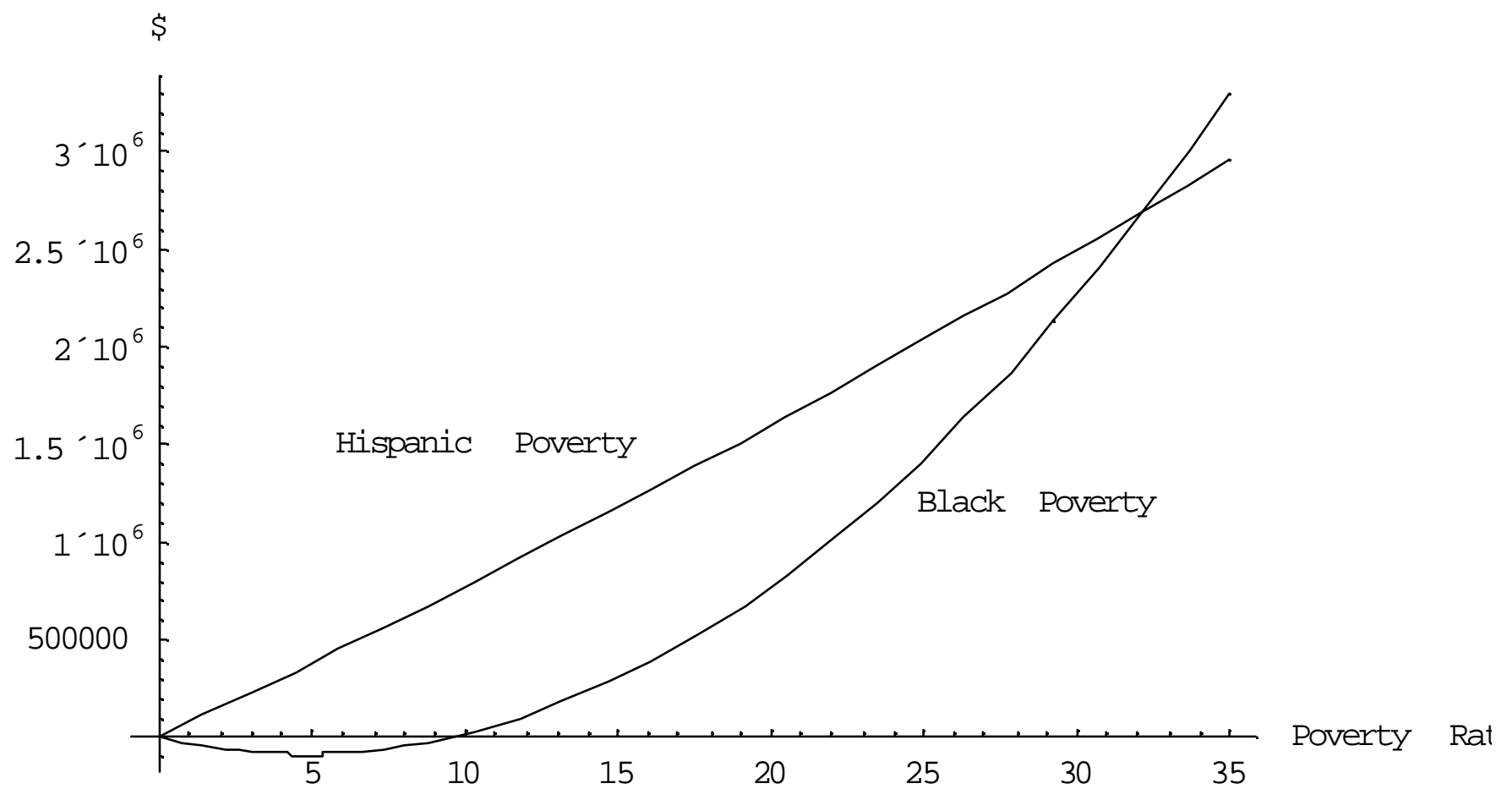

Figure 4: Awards Decline in Poverty Rates at Low Poverty Rates but Increase Rapidly at Higher Rates 


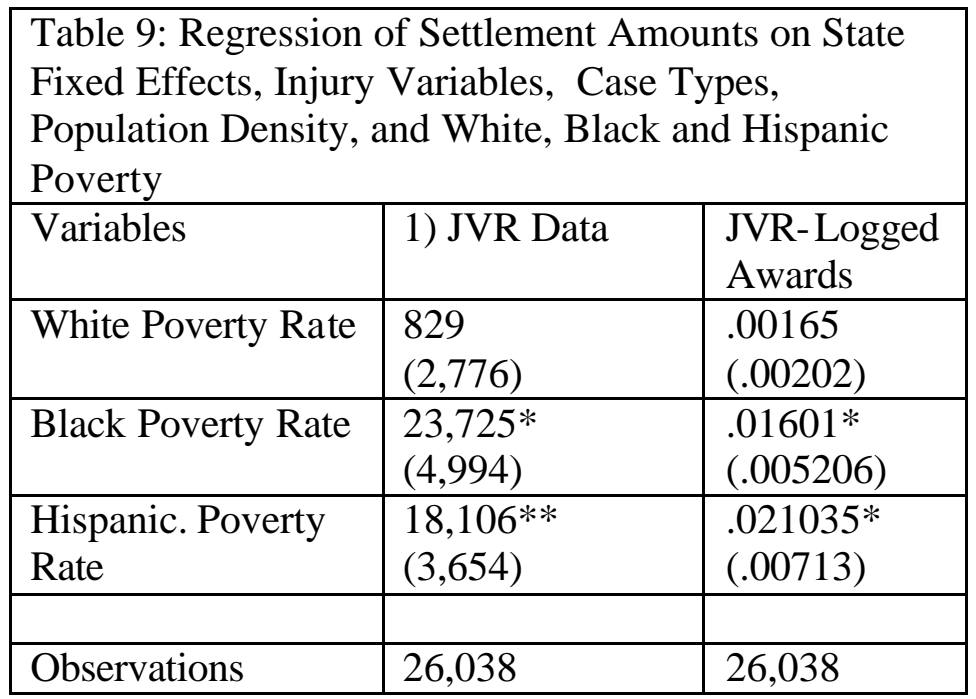

* Significant at greater than $1 \%$ level.

**Significant at greater than $5 \%$ level.

***Significant at greater than $10 \%$ level.

Standard errors are robust (heterosecadasticconsistent).

All awards in 1996 dollars 


\section{Appendix One}

Table A1: Regression of Total Award on State Fixed Effects, Injury Variables, Case Types, Population Density, and White, Black and Hispanic Poverty (Full Results for Model 1 of Table 7 - other models are similar.)

\begin{tabular}{|c|c|c|c|c|}
\hline Variable & Coefficient & Standard Error & T-Stat & P-Value \\
\hline $\mathrm{ak}$ & 1063971 & 337437.9 & 3.15 & 0.002 \\
\hline al & 1547308 & 283825.8 & 5.45 & 0.000 \\
\hline ar & 778653.4 & 175031.3 & 4.45 & 0.000 \\
\hline $\mathrm{az}$ & 968921.3 & 214207.7 & 4.52 & 0.000 \\
\hline $\mathrm{ca}$ & 998778.9 & 156964.6 & 6.36 & 0.000 \\
\hline co & 813218.9 & 181763.1 & 4.47 & 0.000 \\
\hline $\mathrm{ct}$ & 884130 & 147366.2 & 6.00 & 0.000 \\
\hline de & 1102901 & 195101.1 & 5.65 & 0.000 \\
\hline $\mathrm{fl}$ & 1090445 & 148212.7 & 7.36 & 0.000 \\
\hline ga & 998918.8 & 165557.2 & 6.03 & 0.000 \\
\hline hi & 1171531 & 156669.7 & 7.48 & 0.000 \\
\hline ia & 1062338 & 155578.6 & 6.83 & 0.000 \\
\hline id & 1317529 & 447910.8 & 2.94 & 0.003 \\
\hline il & 1327268 & 188849 & 7.03 & 0.000 \\
\hline $\sin$ & 1617471 & 313222.2 & 5.16 & 0.000 \\
\hline ks & 912049.1 & 154392.7 & 5.91 & 0.000 \\
\hline ky & 1265558 & 177055.6 & 7.15 & 0.000 \\
\hline la & 889024.9 & 180449.5 & 4.93 & 0.000 \\
\hline $\mathrm{ma}$ & 1058158 & 158060.6 & 6.69 & 0.000 \\
\hline md & 1235347 & 199370.4 & 6.20 & 0.000 \\
\hline me & 1118002 & 173751 & 6.43 & 0.000 \\
\hline $\mathrm{mi}$ & 802458.4 & 154585.7 & 5.19 & 0.000 \\
\hline $\mathrm{mn}$ & 1092889 & 60556.96 & 18.05 & 0.000 \\
\hline mo & 1035344 & 162945.4 & 6.35 & 0.000 \\
\hline $\mathrm{ms}$ & 834108 & 213014.7 & 3.92 & 0.000 \\
\hline $\mathrm{mt}$ & 1006535 & 160841.1 & 6.26 & 0.000 \\
\hline $\mathrm{nc}$ & 1222591 & 193956.1 & 6.30 & 0.000 \\
\hline nd & 1161863 & 161627.7 & 7.19 & 0.000 \\
\hline ne & 1143842 & 247899.3 & 4.61 & 0.000 \\
\hline $\mathrm{nh}$ & 1088171 & 158603.8 & 6.86 & 0.000 \\
\hline nj & 783087.3 & 149232.2 & 5.25 & 0.000 \\
\hline $\mathrm{nm}$ & 429437.2 & 196311.2 & 2.19 & 0.029 \\
\hline nv & 1290039 & 388314 & 3.32 & 0.001 \\
\hline ny & 1600510 & 184299.2 & 8.68 & 0.000 \\
\hline oh & 954883.9 & 149166.4 & 6.40 & 0.000 \\
\hline ok & 909905 & 153608.3 & 5.92 & 0.000 \\
\hline or & 1391103 & 447252.9 & 3.11 & 0.002 \\
\hline
\end{tabular}




\begin{tabular}{lllll} 
pa & 883972.5 & 153514.8 & 5.76 & 0.000 \\
ri & 1060093 & 175901.7 & 6.03 & 0.000 \\
sc & 1166461 & 233831.4 & 4.99 & 0.000 \\
sd & 1303885 & 208944.9 & 6.24 & 0.000 \\
tn & 1024050 & 160570.6 & 6.38 & 0.000 \\
tx & 1074681 & 176971.4 & 6.07 & 0.000 \\
ut & 634346 & 181510.5 & 3.49 & 0.000 \\
va & 1058124 & 156621.4 & 6.76 & 0.000 \\
vt & 848251.9 & 172565.6 & 4.92 & 0.000 \\
wa & 965359.6 & 147867.1 & 6.53 & 0.000 \\
wi & 1313519 & 215407.9 & 6.10 & 0.000 \\
wv & 1117452 & 181206.2 & 6.17 & 0.000 \\
wy & 984193.7 & 179234.7 & 5.49 & 0.000 \\
death & 440672.9 & 160689.5 & 2.74 & 0.006 \\
major & 1174859 & 161633.7 & 7.27 & 0.000 \\
minor & -769030.1 & 135828.8 & -5.66 & 0.000 \\
emot & -630898.8 & 156052.6 & -4.04 & 0.000 \\
rape & 135922.6 & 290794 & 0.47 & 0.640 \\
sexaslt & 779228.6 & 461820.4 & 1.69 & 0.092 \\
sexharas & -903116.6 & 152796.7 & -5.91 & 0.000 \\
wrongful & -437427.6 & 176830.4 & -2.47 & 0.013 \\
permlia & -347639.5 & 52009.94 & -6.68 & 0.000 \\
medmal & 456481.9 & 98499.13 & 4.63 & 0.000 \\
employer & 130479.8 & 78166.4 & 1.67 & 0.095 \\
badfaith & 651067.2 & 314785.8 & 2.07 & 0.039 \\
prodliab & 1031030 & 170143.7 & 6.06 & 0.000 \\
auto & -338001 & 44938.66 & -7.52 & 0.000 \\
density & 5.126861 & 4.271742 & 1.20 & 0.230 \\
wpov & -8644.593 & 2876.443 & -3.01 & 0.003 \\
bpov & 19838.69 & 6762.72 & 2.93 & 0.003 \\
hpov & 78588.45 & 15708.8 & 5.00 & 0.000 \\
\hline \hline & & & & \\
\hline
\end{tabular}


Table A2: Regression of Total Award on State Fixed Effects, Case Types, and black and Hispanic Poverty, State Court Data (Full Results for Model 3 of Table 7)

\begin{tabular}{|c|c|c|c|c|}
\hline $\begin{array}{l}\text { Variable } \\
\end{array}$ & Coefficient & Std. Error & t-Statistic & P-Value \\
\hline$\overline{A Z}$ & -73245.51 & 651819.1 & -0.11 & 0.911 \\
\hline $\mathrm{CA}$ & 236018.4 & 606197.4 & 0.39 & 0.697 \\
\hline $\mathrm{CT}$ & -361882.3 & 547124.5 & -0.66 & 0.508 \\
\hline FL & -246665.7 & 571390.5 & -0.43 & 0.666 \\
\hline GA & -1293161 & 658399 & -1.96 & 0.050 \\
\hline $\mathrm{HI}$ & -313737 & 556157.5 & -0.56 & 0.573 \\
\hline IL & -199872.9 & 553082.9 & -0.36 & 0.718 \\
\hline IN & -758602.6 & 604501 & -1.25 & 0.210 \\
\hline KY & -628553 & 697181.2 & -0.90 & 0.367 \\
\hline MA & -218500.8 & 578271.8 & -0.38 & 0.706 \\
\hline MI & -683485.2 & 626681.3 & -1.09 & 0.276 \\
\hline $\mathrm{MN}$ & -477518.4 & 600428.7 & -0.80 & 0.427 \\
\hline MO & -640649.6 & 518311.1 & -1.24 & 0.217 \\
\hline NJ & -481101.4 & 530400.2 & -0.91 & 0.364 \\
\hline NY & 2078866 & 922286.9 & 2.25 & 0.024 \\
\hline $\mathrm{OH}$ & -656170.4 & 612902.8 & -1.07 & 0.284 \\
\hline PA & -453949.1 & 588478.4 & -0.77 & 0.441 \\
\hline TX & 887456.1 & 882343.5 & 1.01 & 0.315 \\
\hline VA & -455931 & 492724.1 & -0.93 & 0.355 \\
\hline WA & -348508.7 & 586807.2 & -0.59 & 0.553 \\
\hline WI & -620220.6 & 639775.8 & -0.97 & 0.332 \\
\hline bdharm & 98303.01 & 270684.6 & 0.36 & 0.717 \\
\hline prharm & -323936.2 & 263330.8 & -1.23 & 0.219 \\
\hline naharm & -195544.8 & 451479.3 & -0.43 & 0.665 \\
\hline auto & 406026.4 & 366701.7 & 1.11 & 0.268 \\
\hline dprop & 288411.3 & 359995.1 & 0.80 & 0.423 \\
\hline prod & 857149.2 & 356536.3 & 2.40 & 0.016 \\
\hline inttort & 453220.8 & 298352.2 & 1.52 & 0.129 \\
\hline medmal & 1420640 & 532720.9 & 2.67 & 0.008 \\
\hline profmal & 1428971 & 504682.6 & 2.83 & 0.005 \\
\hline libel & 376415.8 & 548328 & 0.69 & 0.492 \\
\hline toxic & 513563.7 & 456721.1 & 1.12 & 0.261 \\
\hline untort & 623539.6 & 520434.2 & 1.20 & 0.231 \\
\hline otort & 606366.2 & 385715.8 & 1.57 & 0.116 \\
\hline confraud & 907209.9 & 911523.3 & 1.00 & 0.320 \\
\hline cfrauds & -117967.6 & 291927.5 & -0.40 & 0.686 \\
\hline cfraudb & 37445.14 & 257540.8 & 0.15 & 0.884 \\
\hline empcon & 1498655 & 921596.6 & 1.63 & 0.104 \\
\hline lease & 1622140 & 1895478 & 0.86 & 0.392 \\
\hline ocon & 79049.79 & 327487.3 & 0.24 & 0.809 \\
\hline eminent & -1987128 & 2118207 & -0.94 & 0.348 \\
\hline realprp & 560122 & 487574.5 & 1.15 & 0.251 \\
\hline
\end{tabular}




\begin{tabular}{lllll} 
orlprp & 357166.1 & 493969.8 & 0.72 & 0.470 \\
density & -21.4473 & 9.921997 & -2.16 & 0.031 \\
wpov & -18199.44 & 30634.32 & -0.59 & 0.552 \\
bpov89 & 74991.7 & 21447.19 & 3.50 & 0.000 \\
hpov89 & -106159.1 & 68608.31 & -1.55 & 0.122 \\
\hline \hline
\end{tabular}


Table A3: Regression of Total Award on Case Types, District Density, Year Dummies and white, black and Hispanic Poverty (Full Results for Model 5 of Table 7)

\begin{tabular}{lllll}
\hline \hline Variable & Coefficient & Std. Error & t-Statistic & P-Value \\
\hline cons & 332020.3 & 271170.1 & 1.22 & 0.221 \\
ldensity & 39952.41 & 36688.92 & 1.09 & 0.276 \\
assault & 11236.43 & 245318.3 & 0.05 & 0.963 \\
marine & -238037.4 & 367909.1 & -0.65 & 0.518 \\
auto & -143818.4 & 98756.15 & -1.46 & 0.145 \\
opinjury & -292304.6 & 99348.06 & -2.94 & 0.003 \\
medmal & -287790.2 & 182122.4 & -1.58 & 0.114 \\
fraud & 88031.87 & 259589.8 & 0.34 & 0.735 \\
prpdam & 63245.29 & 280394.9 & 0.23 & 0.822 \\
y89 & -160877.8 & 93927.82 & -1.71 & 0.087 \\
y90 & 550782.3 & 111335.8 & 4.95 & 0.000 \\
y91 & 1185668 & 143722.4 & 8.25 & 0.000 \\
y92 & 1125907 & 124411.8 & 9.05 & 0.000 \\
wpov & 19665.14 & 8209.389 & 2.40 & 0.017 \\
bpov & 18875.03 & 10152.29 & 1.86 & 0.063 \\
hpov & 12344.97 & 27405.61 & 0.45 & 0.652
\end{tabular}

